\title{
Lipid Rafts in Mast Cell Biology
}

\section{Adriana Maria Mariano Silveira e Souza, Vivian Marino Mazucato, Maria Célia Jamur, and Constance Oliver}

Departamento de Biologia Celular e Molecular e Biagentes Patogênicos, Faculdade de Medicina de Ribeirão Preto, Universidade de São Paulo, Avenida Bandeirantes, 3900, 14049-900 Ribeirão Preto, Brazil

Correspondence should be addressed to Constance Oliver, coliver@fmrp.usp.br

Received 13 September 2010; Accepted 28 December 2010

Academic Editor: Rhoderick Brown

Copyright ( 2011 Adriana Maria Mariano Silveira e Souza et al. This is an open access article distributed under the Creative Commons Attribution License, which permits unrestricted use, distribution, and reproduction in any medium, provided the original work is properly cited.

\begin{abstract}
Mast cells have long been recognized to have a direct and critical role in allergic and inflammatory reactions. In allergic diseases, these cells exert both local and systemic responses, including allergic rhinitis and anaphylaxis. Mast cell mediators are also related to many chronic inflammatory conditions. Besides the roles in pathological conditions, the biological functions of mast cells include roles in innate immunity, involvement in host defense mechanisms against parasites, immunomodulation of the immune system, tissue repair, and angiogenesis. Despite their growing significance in physiological and pathological conditions, much still remains to be learned about mast cell biology. This paper presents evidence that lipid rafts or raft components modulate many of the biological processes in mast cells, such as degranulation and endocytosis, play a role in mast cell development and recruitment, and contribute to the overall preservation of mast cell structure and organization.
\end{abstract}

\section{Introduction}

Mast cells, like blood cells, are derived from pluripotent bone marrow hematopoietic stem cells but, unlike blood cells, they leave the bone marrow as progenitors and migrate into virtually all vascularized tissues to complete their differentiation under the influence of factors present at each tissue site. It is the microenvironment surrounding the mast cells that determines their mature phenotype [1-6]. Mast cells are effector cells of allergic and anaphylactic reactions and play a role in many physiological and pathological processes $[7,8]$. Recently, they have gained new importance as immunoregulatory cells with the recognition that they are a major source of cytokines and chemokines and play roles in both innate and adaptive immunities $[7,9,10]$. Although mast cells may be activated by a number of stimuli and pathways $[11,12]$, the major mechanism for their activation and subsequent degranulation is through the high-affinity receptor for immunoglobulin $\mathrm{E}$ ( $\mathrm{F}_{c \varepsilon R \mathrm{RI}}$ ), present in the plasma membrane of mast cells, epidermal Langerhans cells, eosinophils, and basophils [13]. FceRI is expressed as a heterotetrameric structure composed of one $\alpha$ subunit with an extracellular domain that binds $\mathrm{IgE}$, a four-transmembrane-spanning $\beta$ subunit, and two identical disulphide linked $\gamma$ subunits [14-17]. The $\beta$ subunit serves as an important amplifier of IgE and antigen-induced signaling events. Furthermore, the $\gamma$ subunits are essential for initiating signaling events downstream of FceRI $[17,18]$. The carboxyl terminal cytoplasmic domains of both the $\beta$ and $\gamma$ subunits contain an immunoreceptor tyrosinebased activation motif (ITAM), common to all multisubunit immune recognition receptors, that is critical for cell activation. Because the receptor subunits lack any known enzymatic activity, FceRI must rely on associated molecules for transducing intracellular signals $[16,19,20]$. Mast cell activation is initiated by the binding of oligomeric antigens to receptor-bound IgE, which crosslinks FcERI and results in its aggregation. The first recognized biochemical event of the cytoplasmic signal transduction cascade involves phosphorylation, presumably by Lyn, of two conserved tyrosine residues within the ITAMs of both $\beta$ and $\gamma$ subunits of the receptor. The tyrosine-phosphorylated ITAMs create a novel binding surface that is recognized by additional cytoplasmic signaling molecules, such as the protein tyrosine kinase Syk 
which binds mainly to the $\gamma$ subunit, via its tandem Src homology 2 (SH2) domains. This interaction results in a conformational change in Syk, followed by its activation and autophosphorylation. This results in an increased kinase activity that rapidly shifts the equilibrium of the cell from a resting state (where phosphorylation and dephosphorylation activities are approximately equal) to an activated state (where phosphorylation activity increases exponentially and cannot be counteracted by dephosphorylation). This Sykmediated signal amplification results in a direct or indirect activation of several proteins, including linker for activation of T cells (LAT), Vav, phospholipase C- $\gamma 1$ (PLC- $\gamma 1)$, and PLC- $\gamma 2$. Finally, downstream activation results in an increase in intracellular calcium levels, activation of other enzymes and adaptors, and rearrangement of the cytoskeleton that culminates in the release of three classes of mediators: (1) preformed mediators (stored in secretory granules), such as histamine, heparin, $\beta$-hexosaminidase, neutral proteases, acid hydrolases, major basic protein, carboxypeptidases, and some cytokines and growth factors, (2) newly formed lipid mediators, such as prostaglandins and leukotrienes, and (3) newly synthesized mediators, that include growth factors, cytokines, and chemokines $[14,21,22]$. Accumulating evidence suggests that lipid rafts or raft components play a pivotal role in signal transduction via FceRI in mast cells and that the organization of various molecules in lipid rafts could modulate many biological processes in these cells.

Lipid rafts, present in all eukaryotic cells, are currently defined as dynamic-ordered nanoscale assemblies of proteins and lipids of the plasma membrane and other intracellular membranes, such as Golgi membranes, that associate and dissociate on a subsecond timescale $[4,23,24]$. They contain high levels of cholesterol, sphingolipids (such as sphingomyelin), and gangliosides. Lipid rafts selectively concentrate glycosylphosphatidylinositol- (GPI-) anchored proteins on their outer side and proteins anchored by saturated palmitoyl or myristoyl groups and cholesterolbinding proteins on the cytoplasmic side [25-29]. Their lipid composition (Figure 1), with a preponderance of longer saturated hydrocarbon chains that potentiate interdigitation between leaflets [30] and favors interaction with cholesterol [31], allows cholesterol to be tightly intercalated. Lipid rafts are highly organized and probably exist in a liquid-ordered $\left(l_{0}\right)$ phase, different from the rest of the plasma membrane which consists mainly of phospholipids (with unsaturated tails) in a liquid-disordered $\left(l_{d}\right)$ phase [32]. The extent of packing depends on the degree of saturation. The cis double bond present on unsaturated lipids introduces a rigid bend in the hydrocarbon tail which interferes with the tight packing and results in less stable aggregates [33]. Lipid rafts are characterized by high melting temperature and a resistance to solubilization in nonionic detergents such as Triton X100 , at low temperature [34]. They are dynamic in that both proteins and lipids can move in and out of raft domains with different partitioning kinetics [28], as well as by coalescing or by breaking up into smaller units [29]. Lipid rafts can also form stabile platforms that are important in signaling, viral infection, and membrane trafficking [24]. Despite a body of evidence supporting the existence of raft domains, the raft concept is still being debated [35] because the mechanisms that govern the associations among sphingolipid, cholesterol, and specific membrane proteins in live cell membranes remain unclear [36]. The controversy is largely due to the lack of standardized methodology for lipid raft studies and the difficulty in proving definitively that rafts exist in living cells without causing significant nonphysiological perturbations by using low temperatures or by extensive crosslinking [37]. The majority of the studies involving lipid rafts begin with detergent solubilization of whole cells followed by sucrose density gradient centrifugation and the recovery of detergent-resistant membranes from the light fractions of the gradient $[19,20]$. However, the analysis of density gradient centrifugation experiments remains controversial because there is an indication that detergents may force associations between components that are not colocalized in intact cells [38]. Fractionation results are also known to be severely altered by varying the concentration of Triton $\mathrm{X}-100[39,40]$, by the use of different detergents, $[41,42]$, or by omission of detergents in general [43-45]. Another difficulty has been demonstrating the coexistence of $l_{o}$ and $l_{d}$ phases in live cells. However, technological advances have produced compelling data that self-organization of lipids and proteins can induce subcompartmentalization that organizes the bioactivity of cell membranes [31]. Recently, the lipid-based phase separation into liquid-ordered-like and liquid-disordered-like phases has been seen in giant plasma membrane vesicles (GPMVs) obtained by chemically induced blebbing from cultured cells $[46,47]$ or by using cell swelling to generate plasma membrane spheres (PMS) [48]. In 2010, Johnson et al. [49] using GPMVs showed that peripheral protein binding may be a regulator for lateral heterogeneity in vivo. These new approaches are very promising, allowing studies of the lipid domains in the absence of detergents and other perturbations of membrane structure. Advances in imaging and studies with improved integrated methodologies, such as flotation of detergentresistant membranes, antibody patching and immunofluorescence microscopy, immunoelectron microscopy, chemical crosslinking, single fluorophore tracking microscopy, photonic force microscopy, spectrofluorimetry, mass spectrometry, and fluorescence resonance energy transfer (FRET) are now providing insights into the existence and behavior of lipid rafts $[2,16,24,50-56]$.

The lipid microdomains are variable in stability, size, shape, lifetime, and molecular composition $[29,37]$. Due to differing molecular composition, studies of lipid rafts have also been complicated by imprecise nomenclature [24]. For example, caveolae was synonymous with lipid rafts for many years. In 1998, Harder et al. [57], using a cell system lacking caveolae, demonstrated that raft and nonraft markers segregated in the same cholesterol-dependent way in the absence of caveolae. These results showed that clustered raft markers segregate away from nonraft proteins in a cholesterol-dependent, but caveolin independent manner [56]. Today caveolae are considered a subset of lipid rafts $[16,58]$.

Membrane rafts in most cell types are enriched with signaling molecules by virtue of the affinity of signaling proteins 

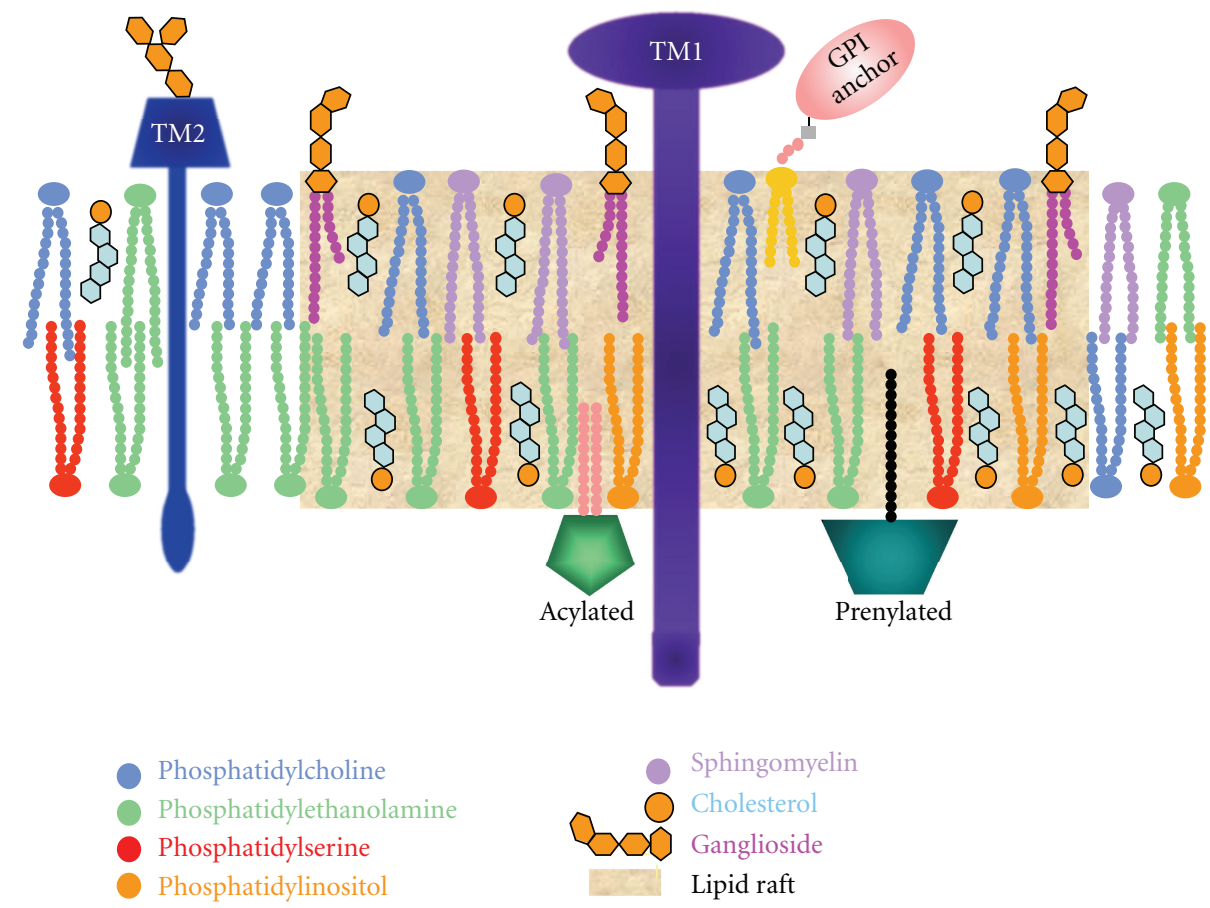

FIGURE 1: Diagrammatic representation of a lipid raft. Lipid rafts are enriched in cholesterol, sphingolipids, and gangliosides. GPI anchored proteins, sphingomyelin, phosphatidylcholine and gangliosides are present in the outer membrane leaflet. Prenylated proteins, acylated proteins, phosphatidlyserine, and phosphatidylethanolamine are present in the inner leaflet. Cholesterol is present in both leaflets and functions as a space filling molecule under the sphingolipid head groups. TM1, TM2, Transmembrane proteins 1 and 2.

including transmembrane receptors, GPI anchored proteins, $\mathrm{G}$ proteins, RhoA and Src kinases for rafts $[1,35]$. The number of proteins reported to be regulated by specific lipid interaction is steadily increasing, but the precise structural mechanisms behind specific binding and receptor regulation in membranes remain uncharacterized [56]. A wealth of biochemical and genetic data have lent credence to the notion that raft function as a specialized signaling platform in cell membranes [59-65]. Most likely, the function of rafts is aided by stimulation-induced association and recruitment of various molecules with raft affinity, as well as varying degrees of raft engagement with the cytoskeleton [3, 4, 29]. Lipid rafts are also thought to be important sites for protein tyrosine kinase-mediated protein-protein interactions that are involved in the initiation of receptor signaling pathways $[5,6,16]$. It is well known that, in the case of tyrosine kinase receptors, adaptors, scaffolding proteins, and enzymes are recruited to the cytoplasmic side of the plasma membrane as a result of ligand binding to form a signaling complex [66]. If receptor activation takes place in an ordered lipid raft, the signaling complex is protected from other proteins, such as membrane phosphatases, localized in the disordered region of the plasma membrane, that otherwise could affect the signaling process $[35,51,67]$. Lipid rafts are implicated in the function of diverse signaling pathways such as those mediated by growth factors, morphogens, integrins [16] and antigen receptors on immune cells, including mast cells [6871]. The structural basis for the association of FceRI with lipid rafts is partially understood and appears to involve the transmembrane segments of Fc\&RI $\alpha$ and/or $\gamma$ subunits. However, the structural features of FceRI that mediate the detergent-sensitive interaction with lipid rafts occur selectively but not uniquely with this receptor [39]. Both $\beta$ and $\gamma$ subunits are palmitoylated, which could facilitate their association with lipid rafts [72].

Studies have shown that establishing and maintaining lipid rafts is important for many biological processes besides cell signaling $[73,74]$. These membrane microdomains have been implicated in such processes as exocytosis, endocytosis, membrane trafficking, and cell adhesion. The structurefunction relationship of lipid rafts or rafts constitutes are important in various aspects of mast cell biology.

\section{Morphology}

The ability to form lipid rafts appears to be important for maintaining the typical morphology of mast cells. Gangliosides (Figure 2), lipid raft components, are complex glycosphingolipids that are ubiquitous membrane constituents $[5,75-77]$ and seem to be structurally important for lipid raft assembly and function. The rigid structural nature of the ceramide anchor in gangliosides, coupled with the ability of sphingolipids to associate with cholesterol, is thought to drive the assembly of lipid rafts $[16,78]$.

The influence of gangliosides and/or lipid rafts on cell structure and organization was examined [79] using a ganglioside-deficient cell line, D1, and the parent cell line, RBL-2H3, a cell line with homology to mucosal mast cells 


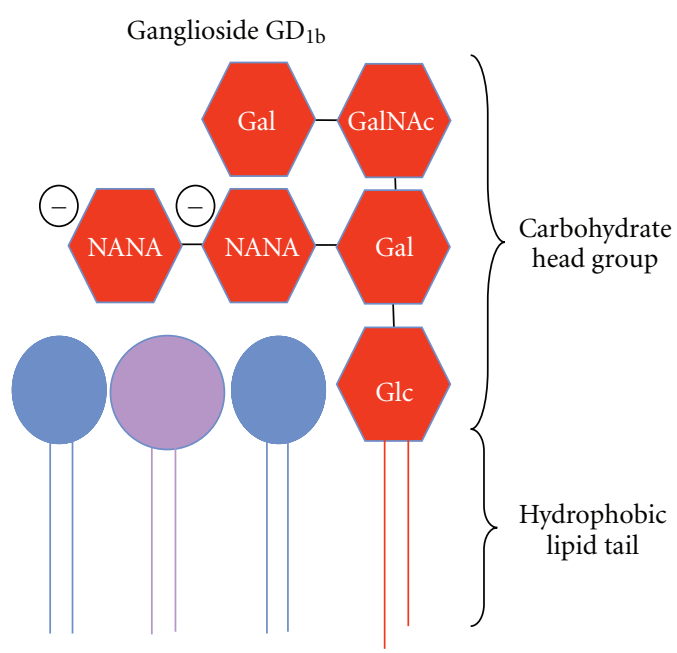

FIgURE 2: Diagrammatic representation of ganglioside $\mathrm{GD}_{1 \mathrm{~b}}$. The ganglioside is composed of a carbohydrate head group and a hydrophobic lipid tail.
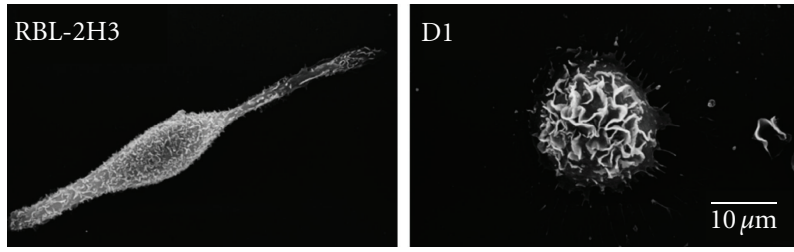

Figure 3: Ganglioside-deficient D1 cells have an altered morphology. By scanning electron microscopy, RBL-2H3 cells are spindle shaped and their surface is covered with short microvilli. In contrast, D1 cells are rounded and their surface is covered with large membrane ruffles.

[80-84]. The D1 cell line is deficient in $\mathrm{GM}_{1}$ gangliosides and in mast cell specific $\alpha$-galactosyl derivatives of the ganglioside $\mathrm{GD}_{1 \mathrm{~b}}$. The $\alpha$-galactosyl derivatives of the ganglioside $\mathrm{GD}_{1 \mathrm{~b}}$, antigens I and II, contain, respectively, one and two additional $\alpha$-galactosyl residues when compared with $\mathrm{GD}_{1 \mathrm{~b}}$. These unique gangliosides are present on the surface of rodent mast cells and are specifically recognized by the monoclonal antibody (mAb) AA4 [85]. These gangliosides derived from $\mathrm{GD}_{1 \mathrm{~b}}$ have been identified as components of lipid rafts in the plasma membrane of RBL-2H3 cells [86, 87]. The mutant cell line D1 showed a cellular morphology which is distinct from RBL-2H3 cells (Figure 3), suggesting that the gangliosides are important in the maintenance of normal cell morphology.

The morphological changes observed in D1 cells could be related to the lipid composition of these cells. This cell line presents a large decrease in glycosphingolipids, such as $\mathrm{GM}_{1}$ and the $\alpha$-galactosyl derivatives of the ganglioside $\mathrm{GD}_{1 \mathrm{~b}}$, which may affect many physicochemical properties of the plasma membrane. According to Kato et al. [88], the lipid composition could influence membrane stability, membrane fluidity, lipid packing, bilayer curvature, and hydration elasticity, as well as anchorage of the cytoskeleton to the plasma membrane. Silveira e Souza et al. [79] also
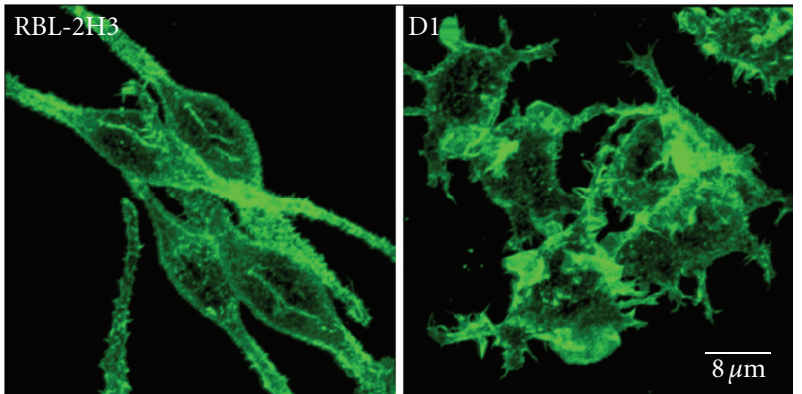

FIgURE 4: The F-actin distribution in RBL-2H3 and D1 cells reflects their morphology. Actin filaments in RBL-2H3 cells lie under the plasma membrane following the spindle shape of the cells and in association with microvilli. The actin cytoskeleton is altered in D1 cells and the actin filaments are concentrated in large membrane ruffles. The cells were fixed, permeabilized, and stained with phalloidin conjugated to Alexa 488. Samples were examined using a Leica TCS-NT laser scanning confocal microscope.

observed that the D1 cells showed an abnormal distribution of actin filaments and microtubules. A growing body of evidence indicates that lipid rafts are essential for membranecytoskeleton coupling, and the association of Lyn and other raft markers with crosslinked FceRI is regulated by interactions with F-actin [89-91]. It is possible that in the D1 mutant cells, the disorganization of both lipid rafts and actin filaments (Figure 4) leads to impaired degranulation after FceRI stimulation [79, 87]. Furthermore, the actin cytoskeleton is known to participate in regulating and activating raft-associated signaling events [92-94].

The factors that govern the formation of lipid rafts continue to be elucidated, but lipid raft formation often requires actin filaments. The connection between lipid raft proteins and actin filaments can affect the lateral distribution and mobility of these membrane proteins [59, 95]. The extent to which the actin cytoskeleton participates in the formation of membrane rafts is not yet established. Han et al. [96] observed that perturbations in the actin filaments (with cytochalasin D and latrunculin A) affect the organization of lipid rafts in RBL-2H3 cells. Importantly, the actin cytoskeleton is a dynamic structure that changes in response to extracellular signals, and it may therefore represent one mechanism for governing the establishment and distribution of lipid rafts in the plasma membrane [97]. Chichili and Rodgers [98] showed that lipid rafts may be structured by a synergistic interaction between the cortical actin filaments and the lipid rafts themselves, and that many of the structural and functional properties of rafts require an intact actin cytoskeleton. An important regulator of membrane-cytoskeleton interactions is the phosphoinositide PIP2, which is a minor lipid component of the plasma membrane that is known to regulate the organization of the actin cytoskeleton and in particular the formation of actin-membrane linkages [99]. PIP2 also serves as a cofactor for many of the proteins that anchor actin filaments to the plasma membrane $[99,100]$. Protein binding to PIP2 often occurs through a PIP2-specific recognition sequence, in many cases represented by a PIP2-specific pleckstrin 


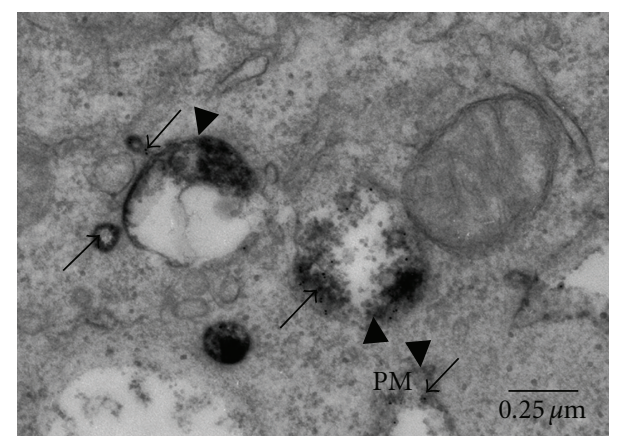

Figure 5: The gangliosides follow the same endocytic pathway as FceRI. At 15 minutes of incubation with both mAb BC4gold (which recognizes the $\alpha$ subunit of FceRI) and mAb AA4$\mathrm{HRP}$ (which recognizes gangliosides derived from $\mathrm{GD}_{1 \mathrm{~b}}$ ), the $\mathrm{BC} 4$ gold (arrows) and AA4-HRP (arrowheads) are colocalized in early endosomes adjacent to the plasma membrane (PM).

homology (PH) domain [101-103]. Some actin binding proteins (ABPs) are thought to link actin filaments and PIP2enriched rafts. Gelsolin is one of the ABPs present in lipid rafts [104]. Microtubules are one of the major determinants of cell shape and polarity $[105,106]$. In the gangliosidedeficient D1 cells, the arrangement of microtubules was completely disorganized. The results from this study have demonstrated that the abnormal morphology observed in the mutant cell line could be related to the decrease in gangliosides that leads to lipid raft disorganization [79].

\section{Endocytosis}

When the concept of lipid rafts and the mobility of proteins in the plasma membrane originated, it was observed that plasma membrane associated proteins could suffer a selective reorganization followed by internalization of these proteins [107-109]. Receptor-mediated endocytosis, including endocytosis of FceRI, is a temporally and spatially organized process $[22,110]$. After activation, crosslinked FceRI is endocytosed through clathrin-coated vesicles and transported by the endosomal system for eventual degradation in lysosomes [111-113]. In unstimulated mast cells, FceRI is dispersed throughout the plasma membrane but upon activation the receptors rapidly aggregate and can be found on the cell surface in lipid rafts in association with $\mathrm{GM}_{1}[114,115]$, gangliosides derived from $\mathrm{GD}_{1 \mathrm{~b}}$, protein tyrosine kinase Lyn and LAT, $[22,39,86]$. However, only when the mast cells are activated via FceRI does a significant internalization of the $\mathrm{GD}_{1 \mathrm{~b}}$ derivatives occur $[22,116]$. The endocytosis process itself may play an important role in signal transduction [110, 117]. Oliver et al. [22] showed that upon activation of FceRI, the gangliosides derived from $\mathrm{GD}_{1 \mathrm{~b}}$ are internalized together with the receptor, following the same pathway to lysosomes (Figure 5). This may facilitate the structural preservation of signaling complexes and the prolongation of the signal since these gangliosides and the FceRI are associated in lipid rafts.

In view of the importance of lipid raft integrity for efficient receptor endocytosis, it has been observed that the FcERI ubiquitination is a key mechanism for the regulation and control of antigen-dependent endocytosis of receptor complexes [118]. Moreover, it has been demonstrated that ubiquitin ligases $\mathrm{Cbl}$ and Nedd 4 are recruited into lipid rafts upon IgE triggered cell signaling [119]. Nedd4 was shown to ubiquitinate membrane receptors [120]. The ubiquitin $\mathrm{Cbl}$ is a good candidate to mediate FceRI ubiquitination since it participates in various functions such as cis-andtrans-ubiquitination [121]. It is phosphorylated upon FceRI engagement [122] and negatively regulates Syk kinase [123]. Molfetta et al. [124, 125] suggested that the recruitment of engaged FceRI subunits into lipid rafts precedes their ubiquitination, and that integrity of lipid rafts is required for receptor ubiquitination and endocytosis, contributing to the down-regulation of FceRI-mediated signaling.

\section{Signal Transduction}

In mast cells, the first signaling complex convincingly shown to involve lipid rafts was immunoglobulin $\mathrm{E}(\mathrm{IgE})$. $\operatorname{IgE}$ signaling was initially thought to be based on protein-protein interactions alone, but several observations indicated that lipid rafts are involved in this process [37, 68, 126-131]. The first hint came from the finding that FceRI is soluble in Triton $\mathrm{X}-100$ at steady state but becomes insoluble in low concentrations of this detergent after crosslinking [68]. Moreover, in unstimulated cells, FceRI is dispersed throughout the plasma membrane, but upon activation rapidly aggregates $[115,132]$ and can then be found on the cell surface in association with the ganglioside $\mathrm{GM}_{1}[57,114,133]$ and GPIanchored proteins $[89,134]$. Despite numerous studies on mast cell activation through FceRI, the detailed mechanism by which cross-linking promotes the initial phosphorylation by Lyn and the molecular mechanisms for Lyn activation are still unclear [67, 77, 135, 136]. Davey et al. [37] suggested that protein-protein interaction (IgE-FceRI cross-linking) recruits essential signaling proteins and lipid molecules into more ordered domains that serve as a platform for signaling.

An approach intensively used to better understand the role of lipid rafts in FceRI-mediated signaling has been the study and/or the manipulation of the lipid constituents of rafts, such as cholesterol and gangliosides [16, 87, 136]. Methyl- $\beta$-cyclodextrin $(\mathrm{M} \beta \mathrm{CD})$, a carbohydrate molecule with a pocket for binding cholesterol, [16] is extensively used to deplete the surface cholesterol and subsequently disrupt lipid rafts. $\mathrm{M} \beta \mathrm{CD}$ has been used to study the role of lipid rafts in FceRI-mediated signaling, particularly in early events of signal transduction such as tyrosine phosphorylation of FceRI by Lyn [136]. Sheets et al. [86] have demonstrated that phosphorylation of FceRI proceeds in a cholesteroldependent manner and that cholesterol depletion reduces stimulated tyrosine phosphorylation of FceRI. In parallel to its inhibition of tyrosine phosphorylation, cholesterol depletion disrupts the interactions of aggregated FceRI and Lyn in intact cells. Cholesterol repletion restores receptor phosphorylation together with the structural interactions, providing strong evidence that lipid raft structure, maintained by cholesterol, plays a critical role in the initiation of FceRI signaling. Cholesterol depletion by $\mathrm{M} \beta \mathrm{CD}$ in RBL-2H3 cells also reduced the release of $\beta$-hexosaminidase activity 
in cells stimulated via FceRI $[87,88,137,138]$. These data suggest that the cholesterol depletion by $M \beta C D$ affects the IgE signaling due to the disruption of lipid rafts and consequently results in a failure to form a signaling complex. Moreover, Young et al. [67] showed evidence that Lyn isolated in lipid rafts has substantially higher Lyn kinase activity than Lyn outside of these membrane microdomains. These data suggest that some unknown components in lipid rafts may influence the kinase activity of Lyn [136] and subsequently FceRI signal transduction.

Flotillin-1 is another constituent of lipid rafts [139, 140]. It was initially identified as a caveolae-associated membrane protein and is a marker protein of lipid rafts, but its physiological role is still not clear. Kato et al. [136] using flotillin-1 knockdown RBL-2H3 cells showed that flotillin-1 regulates the kinase activity of Lyn in mast cells. In the flotillin-1 knockdown cells, there was a significant decrease in $\mathrm{Ca}^{2+}$ mobilization, the phosphorylation of ERKs, tyrosine phosphorylation of the $\gamma$-subunit of FceRI, and IgE-mediated degranulation. This study also showed that flotillin-1 is constitutively associated with Lyn in lipid rafts in RBL-2H3 cells, and that antigen stimulation induced an increase in flotillin-1 binding to Lyn, resulting in enhancement of the kinase activity of Lyn. These data suggest that this raft protein is an important component of FceRI-mediated mast cell activation and regulates the kinase activity of Lyn in lipid rafts.

The $\alpha$-galactosyl derivatives of the gangliosides $\mathrm{GD}_{1 \mathrm{~b}}$ also seem to be intimately involved with signaling through FceRI. Although the functional role of these gangliosides is not clear, previous studies have shown that when the $\alpha$-galactosyl derivatives of ganglioside $\mathrm{GD}_{1 \mathrm{~b}}$ are bound by $\mathrm{mAb}$ AA4, histamine release was inhibited in a time- and concentration-dependent manner. Binding of mAb AA4 to $\mathrm{RBL}-2 \mathrm{H} 3$ cells resulted in an increase in intracellular calcium, phosphatidylinositol hydrolysis, and a redistribution of PKC. However, the magnitude of these changes was less than those after FceRI aggregation, and unlike FceRI activation, these changes were not accompanied by histamine release [81]. The derivatives of the ganglioside $\mathrm{GD}_{1 \mathrm{~b}}$ coprecipitated with the Src family tyrosine kinase Lyn and that in spite of the fact that mAb AA4 binds to sites close to FceRI the association between Lyn and these gangliosides was not mediated by FceRI. The association of Lyn with these gangliosides is much stronger than the association of Lyn with FceRI. These associations suggest that a complex of molecules that includes gangliosides, FceRI, and Lyn is essential for modulation of signal transduction in mast cells [81, 141-144].

Furthermore, analysis of the subcellular distribution of the gangliosides recognized by mAb AA4 and of FceRI on sucrose gradients showed that, following FceRI activation, there was a shift in the distribution of the gangliosides to the lipid raft fractions [22, 87]. The movement of these gangliosides into the lipid rafts may be another mechanism that regulates signal transduction in mast cells.

As previously stated, using a cell line deficient in the $\alpha$-galactosyl derivatives of ganglioside $\mathrm{GD}_{1 \mathrm{~b}}$, as well as the parent cell line, RBL-2H3, Silveira e Souza et al.
[87] demonstrated and confirmed the importance of these gangliosides for lipid raft organization and consequently for FceRI-mediated degranulation in rodent mast cells. In this study, the authors observed a decreased release of $\beta$ hexosaminidase activity in the mutant cell line after FceRI stimulation, but not after exposure to calcium ionophore. These results show that release of $\beta$-hexosaminidase activity is calcium-dependent and furthermore indicated that the mutant cell line possesses the capacity to degranulate. Moreover, reduced release of $\beta$-hexosaminidase activity in RBL$2 \mathrm{H} 3$ cells treated with compounds that inhibit ganglioside synthesis was also observed.

In addition to lipid raft assembly, another possible role for the mast cell-specific gangliosides in signal transduction could be to facilitate the association of Lyn with FceRI. Because FceRI itself has no intrinsic kinase activity, the tyrosine phosphorylations induced by receptor cross-linking could be a secondary event that occurs after aggregation of FceRI and its movement into lipid rafts [143]. Therefore, these lipid raft complexes that include gangliosides, associated proteins, such as Lyn, LAT, flotillin-1 and FceRI, have an important role in receptor-mediated signal transduction.

Recently, Fifadara et al. [8] reported that mast cells produce structures such as cytonemes or tunneling nanotubes used for intercellular communication and that intercellular communication may be important during allergic and inflammatory responses following costimulation of FceRI and CCR1. Albeit the process of cytoneme formation remains poorly understood, the fact that cholesterol depletion reduced the formation of cytonemes suggests that lipid rafts may participate in cytoneme formation in mast cells, either by promoting membrane integrity or by participating in cell signaling.

\section{Mast Cell Development and Recruitment}

The expression of the $\alpha$-galactosyl derivatives of the ganglioside $\mathrm{GD}_{1 \mathrm{~b}}$ on the mast cell surface also appears to be related to mast cell development and recruitment. Previous studies using mAb AA4 showed that the $\alpha$-galactosyl derivatives of the ganglioside $\mathrm{GD}_{1 \mathrm{~b}}$ were present only in mast cells and not in any other cell type in all 23 rat tissues examined $[81,85]$. However, in bone marrow, a population of large, poorly differentiated cells, presumably immature mast cells were also stained with mAb AA4 [81]. Later these cells were indeed shown to be very immature and immature mast cells $[145,146]$. Since the heterogeneity of the maturing mast cells makes them impossible to separate from other cells on the basis of their density and mAb AA4 binds only to cells which can be identified as mast cells [146, 147], the gangliosides recognized by mAb AA4 may be considered a powerful marker for rodent mast cells.

The ability to characterize the maturation of bone marrow-derived and peritoneal mast cells has been impaired both by the lack of mast cell-specific markers and by the inability to rapidly and efficiently separate mast cells in all stages of maturation from a mixed population of cells [148]. Using mAb AA4 conjugated to tosylactivated Dynabeads 450, Jamur et al. [145] successfully separated mast cells from 
rat bone marrow and the peritoneal lavage. They [146] then went on to isolate and characterize bone marrow mast cells at various stages of maturation. In this study, the very immature mast cells, which had not been previously described, were identified by the presence of the derivatives of the ganglioside $\mathrm{GD}_{1 \mathrm{~b}}$ on their surface. These cells which could not be recognized as mast cells by standard cytological methods contained only a few small cytoplasmic granules. On the other hand, undifferentiated mast cell precursors in the bone marrow do not express the $\alpha$-galactosyl derivatives of the ganglioside $\mathrm{GD}_{1 \mathrm{~b}}$ recognized by mAb AA4. These gangliosides begin to be expressed on the cell surface jointly with FceRI and at the same time as the initiation of the formation of cytoplasmic granules in very immature mast cells. The gangliosides derived from $\mathrm{GD}_{1 \mathrm{~b}}$ continue to be expressed by mast cells in all stages of maturation [149]. These data suggest that mast cell lipid rafts or raft constitutes are related to mast cell maturation and function.

\section{Conclusions}

Several aspects of raft structure and function in mast cell biology still need to be elucidated. Undoubtedly, lipid rafts and their constitutes play a role in many aspects of mast cell biology, such as activation through FceRI, morphology, endocytosis, and maturation. Further research to better define the role of lipid rafts in mast cells could offer novel targets for immunotherapies and treatment of diseases in which mast cells and/or their mediators are involved.

\section{Acknowledgment}

A. M. M. Silveira e Souza and V. M. Mazucato contributed equally to this work.

\section{References}

[1] M. L. Allende and R. L. Proia, "Sphingosine-1-phosphate receptors and the development of the vascular system," Biochimica et Biophysica Acta, vol. 1582, no. 1-3, pp. 222227, 2002.

[2] A. Pralle, P. Keller, E. L. Florin, K. Simons, and J. K. H. Hörber, "Sphingolipid-cholesterol rafts diffuse as small entities in the plasma membrane of mammalian cells," Journal of Cell Biology, vol. 148, no. 5, pp. 997-1007, 2000.

[3] A. Kusumi, H. Ike, C. Nakada, K. Murase, and T. Fujiwara, "Single-molecule tracking of membrane molecules: plasma membrane compartmentalization and dynamic assembly of raft-philic signaling molecules," Seminars in Immunology, vol. 17, no. 1, pp. 3-21, 2005.

[4] J. F. Hancock, "Lipid rafts: contentious only from simplistic standpoints," Nature Reviews Molecular Cell Biology, vol. 7, no. 6, pp. 456-462, 2006.

[5] L. J. Pike, "Lipid rafts: heterogeneity on the high seas," Biochemical Journal, vol. 378, no. 2, pp. 281-292, 2004.

[6] A. M. Gilfillan and C. Tkaczyk, "Integrated signalling pathways for mast-cell activation," Nature Reviews Immunology, vol. 6, no. 3, pp. 218-230, 2006.
[7] K. N. Rao and M. A. Brown, "Mast cells: multifaceted immune cells with diverse roles in health and disease," Annals of the New York Academy of Sciences, vol. 1143, pp. 83-104, 2008.

[8] N. H. Fifadara, F. Beer, S. Ono, and S. J. Ono, "Interaction between activated chemokine receptor 1 and FceRI at membrane rafts promotes communication and F-actinrich cytoneme extensions between mast cells," International Immunology, vol. 22, no. 2, pp. 113-128, 2010.

[9] J. Kalesnikoff and S. J. Galli, "New developments in mast cell biology," Nature Immunology, vol. 9, no. 11, pp. 1215-1223, 2008.

[10] M. A. Beaven, "Our perception of the mast cell from Paul Ehrlich to now," European Journal of Immunology, vol. 39, no. 1, pp. 11-25, 2009.

[11] E. Crivellato, D. Ribatti, F. Mallardi, and C. A. Beltrami, "The mast cell: a multifunctional effector cell," Advances in Clinical Pathology, vol. 7, no. 1, pp. 13-26, 2003.

[12] P. A. de Almeida Buranello,, M. R. Moulin, D. A. Souza, M. C. Jamur, M. C. Roque-Barreira, and C. Oliver, "The lectin ArtinM induces recruitment of rat mast cells from the bone marrow to the peritoneal cavity," PLoS One, vol. 5, no. 3, article e9776, 2010.

[13] D. Von Bubnoff, N. Novak, S. Kraft, and T. Bieber, "The central role of FceRi in allergy," Clinical and Experimental Dermatology, vol. 28, no. 2, pp. 184-187, 2003.

[14] H. Metzger, "The receptor with high affinity for IgE," Immunological Reviews, no. 125, pp. 37-48, 1992.

[15] J. P. Kinet, "The high-affinity $\operatorname{IgE}$ receptor (FceRI): from physiology to pathology," Annual Review of Immunology, vol. 17, pp. 931-972, 1999.

[16] K. Simons and D. Toomre, "Lipid rafts and signal transduction," Nature Reviews, vol. 1, no. 1, pp. 31-39, 2000.

[17] J. Rivera, "Molecular adapters in FceRI signaling and the allergic response," Current Opinion in Immunology, vol. 14, no. 6, pp. 688-693, 2002.

[18] M. J. S. Nadler, S. A. Matthews, H. Turner, and J. P. Kinet, "Signal transduction by the high-affinity immunoglobulin E receptor FceRI: coupling form to function," Advances in Immunology, vol. 76, pp. 325-355, 2000.

[19] J. Rivera, R. Arudchandran, C. Gonzalez-Espinosa, T. S. Manetz, and S. Xirasagar, "A perspective: regulation of IgE receptor-mediated mast cell responses by a LAT-organized plasma membrane-localized signaling complex," International Archives of Allergy and Immunology, vol. 124, no. 1-3, pp. 137-141, 2001.

[20] T. Kimura, M. Hisano, Y. Inoue, and M. Adachi, "Tyrosine phosphorylation of the linker for activator of $\mathrm{T}$ cells in mast cells by stimulation with the high affinity IgE receptor," Immunology Letters, vol. 75, no. 2, pp. 123-129, 2001.

[21] R. P. Siraganian, "Mast cell signal transduction from the high-affinity IgE receptor," Current Opinion in Immunology, vol. 15, no. 6, pp. 639-646, 2003.

[22] C. Oliver, A. Fujimura, A. M. M. Silveira e Souza, R. O. De Castro, R. P. Siraganian, and M. C. Jamur, "Mast cell-specific gangliosides and FceRI follow the same endocytic pathway from lipid rafts in RBL-2H3 cells," Journal of Histochemistry and Cytochemistry, vol. 55, no. 4, pp. 315-325, 2007.

[23] L. J. Pike, "Rafts defined: a report on the Keystone symposium on lipid rafts and cell function," Journal of Lipid Research, vol. 47, no. 7, pp. 1597-1598, 2006.

[24] K. Simons and M. J. Gerl, "Revitalizing membrane rafts: new tools and insights," Nature Reviews Molecular Cell Biology, vol. 11, no. 10, pp. 688-699, 2010. 
[25] K. Simons and E. Ikonen, "Functional rafts in cell membranes," Nature, vol. 387, no. 6633, pp. 569-572, 1997.

[26] K. A. Melkonian, A. G. Ostermeyer, J. Z. Chen, M. G. Roth, and D. A. Brown, "Role of lipid modifications in targeting proteins to detergent-resistant membrane rafts. Many raft proteins are acylated, while few are prenylated," Journal of Biological Chemistry, vol. 274, no. 6, pp. 3910-3917, 1999.

[27] L. J. Pike, "Lipid rafts: bringing order to chaos," Journal of Lipid Research, vol. 44, no. 4, pp. 655-667, 2003.

[28] L. Rajendran and K. Simons, "Lipid rafts and membrane dynamics," Journal of Cell Science, vol. 118, no. 6, pp. 10991102, 2005.

[29] Á. Szöor, J. Szöllosi, and G. Vereb, "Rafts and the battleships of defense: the multifaceted microdomains for positive and negative signals in immune cells," Immunology Letters, vol. 130, no. 1-2, pp. 2-12, 2010.

[30] P. S. Niemelä, M. T. Hyvönen, and I. Vattulainen, "Influence of chain length and unsaturation on sphingomyelin bilayers," Biophysical Journal, vol. 90, no. 3, pp. 851-863, 2006.

[31] D. Lingwood and K. Simons, "Lipid rafts as a membraneorganizing principle," Science, vol. 327, no. 5961, pp. 46-50, 2010.

[32] K. Simons and W. L. C. Vaz, "Model systems, lipid rafts, and cell membranes," Annual Review of Biophysics and Biomolecular Structure, vol. 33, pp. 269-295, 2004.

[33] X. M. Li, M. M. Momsen, J. M. Smaby, H. L. Brockman, and R. E. Brown, "Cholesterol decreases the interfacial elasticity and detergent solubility of sphingomyelins," Biochemistry, vol. 40, no. 20, pp. 5954-5963, 2001.

[34] D. A. Brown and J. K. Rose, "Sorting of GPI-anchored proteins to glycolipid-enriched membrane subdomains during transport to the apical cell surface," Cell, vol. 68, no. 3, pp. 533-544, 1992.

[35] M. Edidin, "The state of lipid rafts: from model membranes to cells," Annual Review of Biophysics and Biomolecular Structure, vol. 32, pp. 257-283, 2003.

[36] H.-J. Kaiser, D. Lingwood, I. Levental et al., "Order of lipid phases in model and plasma membranes," Proceedings of the National Academy of Sciences of the United States of America, vol. 106, no. 39, pp. 16645-16650, 2009.

[37] A. M. Davey, R. P. Walvick, Y. Liu, A. A. Heikal, and E. D. Sheets, "Membrane order and molecular dynamics associated with IgE receptor cross-linking in mast cells," Biophysical Journal, vol. 92, no. 1, pp. 343-355, 2007.

[38] S. Mayor and F. R. Maxfield, "Insolubility and redistribution of GPI-anchored proteins at the cell surface after detergent treatment," Molecular Biology of the Cell, vol. 6, no. 7, pp. 929-944, 1995.

[39] K. A. Field, D. Holowka, and B. Baird, "Structural aspects of the association of FceRI with detergent-resistant membranes," Journal of Biological Chemistry, vol. 274, no. 3, pp. 1753-1758, 1999.

[40] I. Parolini, S. Topa, M. Sorice et al., "Phorbol esterinduced disruption of the CD4-Lck complex occurs within a detergent-resistant microdomain of the plasma membrane: involvement of the translocation of activated protein kinase C isoforms," Journal of Biological Chemistry, vol. 274, no. 20, pp. 14176-14187, 1999.

[41] C. Montixi, C. Langlet, A. M. Bernard et al., "Engagement of $\mathrm{T}$ cell receptor triggers its recruitment to low-density detergent-insoluble membrane domains," EMBO Journal, vol. 17, no. 18, pp. 5334-5348, 1998.

[42] Z. Surviladze, L. Dráberová, L. Kubínová, and P. Dráber, "Functional heterogeneity of Thy-1 membrane microdomains in rat basophilic leukemia cells," European Journal of Immunology, vol. 28, no. 6, pp. 1847-1858, 1998.

[43] S. Ilangumaran, S. Arni, G. Van Echten-Deckert, B. Borisch, and D. C. Hoessli, "Microdomain-dependent regulation of Lck and Fyn protein-tyrosine kinases in T lymphocyte plasma membranes," Molecular Biology of the Cell, vol. 10, no. 4, pp. 891-905, 1999.

[44] T. Harder and M. Kuhn, "Selective accumulation of raftassociated membrane protein LAT in T cell receptor signaling assemblies," Journal of Cell Biology, vol. 151, no. 2, pp. 199207, 2000.

[45] T. Yamanaka, A. Straumfors, H. C. Morton, O. Fausa, P. Brandtzaeg, and I. N. Farstad, "Differential sensitivity to acute cholesterol lowering of activation mediated via the high-affinity IgE receptor and Thy-1 glycoprotein," European Journal of Immunology, vol. 31, no. 1, pp. 1-10, 2001.

[46] T. Baumgart, A. T. Hammond, P. Sengupta et al., "Largescale fluid/fluid phase separation of proteins and lipids in giant plasma membrane vesicles," Proceedings of the National Academy of Sciences of the United States of America, vol. 104, no. 9, pp. 3165-3170, 2007.

[47] P. Sengupta, A. Hammond, D. Holowka, and B. Baird, "Structural determinants for partitioning of lipids and proteins between coexisting fluid phases in giant plasma membrane vesicles," Biochimica et Biophysica Acta, vol. 1778, no. 1, pp. 20-32, 2008.

[48] D. Lingwood, J. Ries, P. Schwille, and K. Simons, "Plasma membranes are poised for activation of raft phase coalescence at physiological temperature," Proceedings of the National Academy of Sciences of the United States of America, vol. 105, no. 29, pp. 10005-10010, 2008.

[49] S. A. Johnson, B. M. Stinson, M. S. Go et al., "Temperaturedependent phase behavior and protein partitioning in giant plasma membrane vesicles," Biochimica et Biophysica Acta, vol. 1798, no. 7, pp. 1427-1435, 2010.

[50] R. Varma and S. Mayor, "GPI-anchored proteins are organized in submicron domains at the cell surface," Nature, vol. 394, no. 6695, pp. 798-801, 1998.

[51] B. S. Wilson, J. R. Pfeiffer, and J. M. Oliver, "Observing FceRI signaling from the inside of the mast cell membrane," Journal of Cell Biology, vol. 149, no. 5, pp. 1131-1142, 2000.

[52] R. G. Parton and A. A. Richards, "Lipid rafts and caveolae as portals for endocytosis: new insights and common mechanisms," Traffic, vol. 4, no. 11, pp. 724-738, 2003.

[53] G. Vereb, J. Matkó, and J. Szöllösi, "Cytometry of fluorescence resonance energy transfer," Methods in Cell Biology, vol. 2004, no. 75, pp. 105-152, 2004.

[54] A. Bíró, L. Cervenak, A. Balogh et al., "Novel anti-cholesterol monoclonal immunoglobulin $\mathrm{G}$ antibodies as probes and potential modulators of membrane raft-dependent immune functions," Journal of Lipid Research, vol. 48, no. 1, pp. 19-29, 2007.

[55] I. Gombos, G. Steinbach, I. Pomozi et al., "Some new faces of membrane microdomains: a complex confocal fluorescence, differential polarization, and FCS imaging study on live immune cells," Cytometry A, vol. 73, no. 3, pp. 220-229, 2008.

[56] Ü. Coskun and K. Simons, "Membrane rafting: from apical sorting to phase segregation," FEBS Letters, vol. 584, no. 9, pp. 1685-1693, 2010.

[57] T. Harder, P. Scheiffele, P. Verkade, and K. Simons, "Lipid domain structure of the plasma membrane revealed by patching of membrane components," Journal of Cell Biology, vol. 141, no. 4, pp. 929-942, 1998. 
[58] R. G. Parton and K. Simons, "The multiple faces of caveolae," Nature Reviews Molecular Cell Biology, vol. 8, no. 3, pp. 185194, 2007.

[59] W. Rodgers and M. Glaser, "Distributions of proteins and lipids in the erythrocyte membrane," Biochemistry, vol. 32, no. 47, pp. 12591-12598, 1993.

[60] P. S. Kabouridis, A. I. Magee, and S. C. Ley, "S-acylation of LCK protein tyrosine kinase is essential for its signalling function in T lymphocytes," EMBO Journal, vol. 16, no. 16, pp. 4983-4998, 1997.

[61] W. Zhang, R. P. Trible, and L. E. Samelson, "LAT palmitoylation: its essential role in membrane microdomain targeting and tyrosine phosphorylation during T cell activation," Immunity, vol. 9, no. 2, pp. 239-246, 1998.

[62] R. Xavier, T. Brennan, Q. Li, C. McCormack, and B. Seed, "Membrane compartmentation is required for efficient $\mathrm{T}$ cell activation," Immunity, vol. 8, no. 6, pp. 723-732, 1998.

[63] S. Roy, R. Luetterforst, A. Harding et al., "Dominant-negative caveolin inhibits H-Ras function by disrupting cholesterolrich plasma membrane domains," Nature Cell Biology, vol. 1, no. 2, pp. 98-105, 1999.

[64] A. Viola, S. Schroeder, Y. Sakakibara, and A. Lanzavecchia, "T lymphocyte costimulation mediated by reorganization of membrane microdomains," Science, vol. 283, no. 5402, pp. 680-682, 1999.

[65] T. Brdička, D. Pavlištová, A. Leo et al., "Phosphoprotein associated with glycosphingolipid-enriched microdomains (PAG), a novel ubiquitously expressed transmembrane adaptor protein, binds the protein tyrosine kinase Csk and is involved in regulation of T cell activation," Journal of Experimental Medicine, vol. 191, no. 9, pp. 1591-1604, 2000.

[66] A. J. Hunter, N. Ottoson, N. Boerth, G. A. Koretzky, and Y. Shimizu, "Cutting edge: a novel function for the SLAP130/FYB adapter protein in $\beta$ integrin signaling and $\mathrm{T}$ lymphocyte migration," Journal of Immunology, vol. 164, no. 3, pp. 1143-1147, 2000.

[67] R. M. Young, D. Holowka, and B. Baird, "A lipid raft environment enhances Lyn kinase activity by protecting the active site tyrosine from dephosphorylation," Journal of Biological Chemistry, vol. 278, no. 23, pp. 20746-20752, 2003.

[68] K. A. Field, D. Holowka, and B. Baird, "FceRI-mediated recruitment of p53/56(lyn) to detergent-resistant membrane domains accompanies cellular signaling," Proceedings of the National Academy of Sciences of the United States of America, vol. 92, no. 20, pp. 9201-9205, 1995.

[69] M. C. Miceli, M. Moran, C. D. Chung, V. P. Patel, T. Low, and W. Zinnanti, "Co-stimulation and counter-stimulation: lipid raft clustering controls TCR signaling and functional outcomes," Seminars in Immunology, vol. 13, no. 2, pp. 115$128,2001$.

[70] P. C. Cheng, B. K. Brown, W. Song, and S. K. Pierce, "Translocation of the B cell antigen receptor into lipid rafts reveals a novel step in signaling," Journal of Immunology, vol. 166, no. 6, pp. 3693-3701, 2001.

[71] D. Holowka and B. Baird, "FceRI as a paradigm for a lipid raft-dependent receptor in hematopoietic cells," Seminars in Immunology, vol. 13, no. 2, pp. 99-105, 2001.

[72] J. P. Kinet, G. Alcaraz, A. Leonard, S. Wank, and H. Metzger, "Dissociation of the receptor for immunoglobulin E in mild detergents," Biochemistry, vol. 24, no. 15, pp. 4117-4124, 1985.

[73] C. Furne, V. Corset, Z. Hérincs, N. Cahuzac, A. O. Hueber, and P. Mehlen, "The dependence receptor DCC requires lipid raft localization for cell death signaling," Proceedings of the
National Academy of Sciences of the United States of America, vol. 103, no. 11, pp. 4128-4133, 2006.

[74] A. Koenig, J. Q. Russell, W. A. Rodgers, and R. C. Budd, "Spatial differences in active caspase- 8 defines its role in T-cell activation versus cell death," Cell Death and Differentiation, vol. 15, no. 11, pp. 1701-1711, 2008.

[75] S. Hakomori -i, "Structure and function of sphingoglycolipids in transmembrane signalling and cell-cell interactions," Biochemical Society Transactions, vol. 21, no. 3, pp. 583-595, 1993.

[76] D. A. Brown and E. London, "Functions of lipid rafts in biological membranes," Annual Review of Cell and Developmental Biology, vol. 14, pp. 111-136, 1998.

[77] P. Dráber and L. Dráberová, "Lipid rafts in mast cell signaling," Molecular Immunology, vol. 38, no. 16-18, pp. 1247-1252, 2002.

[78] T. Kolter, R. L. Proia, and K. Sandhoff, "Combinatorial ganglioside biosynthesis," Journal of Biological Chemistry, vol. 277, no. 29, pp. 25859-25862, 2002.

[79] A. M. M. Silveira e Souza, E. S. Trindade, M. C. Jamur, and C. Oliver, "Gangliosides are important for the preservation of the structure and organization of RBL-2H3 mast cells," Journal of Histochemistry and Cytochemistry, vol. 58, no. 1, pp. 83-93, 2010.

[80] S. J. Galli, "New insights into 'The riddle of the mast cells': microenvironmental regulation of mast cell development and phenotypic heterogeneity," Laboratory Investigation, vol. 62, no. 1, pp. 5-33, 1990.

[81] C. Oliver, N. Sahara, S. Kitani, A. R. Robbins, L. M. Mertz, and R. P. Siraganian, "Binding of monoclonal antibody AA4 to gangliosides on rat basophilic leukemia cells produces changes similar to those seen with Fce receptor activation," Journal of Cell Biology, vol. 116, no. 3, pp. 635-646, 1992.

[82] L. C. J. Yong, "The mast cell: origin, morphology, distribution, and function," Experimental and Toxicologic Pathology, vol. 49, no. 6, pp. 409-424, 1997.

[83] D. D. Metcalfe, D. Baram, and Y. A. Mekori, "Mast cells," Physiological Reviews, vol. 77, no. 4, pp. 1033-1079, 1997.

[84] E. Passante and N. Frankish, "The RBL-2H3 cell line: its provenance and suitability as a model for the mast cell," Inflammation Research, vol. 58, no. 11, pp. 737-745, 2009.

[85] N. Guo, G. R. Her, V. N. Reinhold, M. J. Brennan, R. P. Siraganian, and V. Ginsburg, "Monoclonal antibody AA4, which inhibits binding of IgE to high affinity receptors on rat basophilic leukemia cells, binds to novel $\alpha$-galactosyl derivatives of gangliosides G(D1b)," Journal of Biological Chemistry, vol. 264, no. 22, pp. 13267-13272, 1989.

[86] E. D. Sheets, D. Holowka, and B. Baird, "Critical role for cholesterol in Lyn-mediated tyrosine phosphorylation of FceRI and their association with detergent-resistant membranes," Journal of Cell Biology, vol. 145, no. 4, pp. 877-887, 1999.

[87] A. M. M. Silveira e Souza, V. M. Mazucato, R. O. de Castro et al., "The $\alpha$-galactosyl derivatives of ganglioside GD are essential for the organization of lipid rafts in RBL-2H3 mast cells," Experimental Cell Research, vol. 314, no. 13, pp. 25152528, 2008.

[88] N. Kato, M. Nakanishi, and N. Hirashima, "Cholesterol depletion inhibits store-operated calcium currents and exocytotic membrane fusion in RBL-2H3 cells," Biochemistry, vol. 42, no. 40, pp. 11808-11814, 2003.

[89] D. Holowka, E. D. Sheets, and B. Baird, "Interactions between FceRI and lipid raft components are regulated by the actin 
cytoskeleton," Journal of Cell Science, vol. 113, no. 6, pp. 1009-1019, 2000.

[90] I. Levitan and K. J. Gooch, "Lipid rafts in membranecytoskeleton interactions and control of cellular biomechanics: actions of oxLDL," Antioxidants and Redox Signaling, vol. 9, no. 9, pp. 1519-1534, 2007.

[91] L. J. Pike, "The challenge of lipid rafts," Journal of Lipid Research, vol. 50, pp. S323-S328, 2009.

[92] S. C. Bunnell, V. Kapoor, R. P. Trible, W. Zhang, and L. E. Samelson, "Dynamic actin polymerization drives $\mathrm{T}$ cell receptor-induced spreading: a role for the signal transduction adaptor LAT," Immunity, vol. 14, no. 3, pp. 315-329, 2001.

[93] M. Barda-Saad, A. Braiman, R. Titerence, S. C. Bunnell, V. A. Barr, and L. E. Samelson, "Dynamic molecular interactions linking the T cell antigen receptor to the actin cytoskeleton," Nature Immunology, vol. 6, no. 1, pp. 80-89, 2005.

[94] T. S. Gomez, M. J. Hamann, S. McCarney et al., "Dynamin 2 regulates $\mathrm{T}$ cell activation by controlling actin polymerization at the immunological synapse," Nature Immunology, vol. 6, no. 3, pp. 261-270, 2005.

[95] P. F. Lenne, L. Wawrezinieck, F. Conchonaud et al., "Dynamic molecular confinement in the plasma membrane by microdomains and the cytoskeleton meshwork," EMBO Journal, vol. 25, no. 14, pp. 3245-3256, 2006.

[96] X. Han, N. L. Smith, D. Sil, D. A. Holowka, F. W. McLafferty, and B. A. Baird, "IgE receptor-mediated alteration of membrane-cytoskeleton interactions revealed by mass spectrometric analysis of detergent-resistant membranes," Biochemistry, vol. 48, no. 27, pp. 6540-6550, 2009.

[97] G. R. Chichili and W. Rodgers, "Clustering of membrane raft proteins by the actin cytoskeleton," Journal of Biological Chemistry, vol. 282, no. 50, pp. 36682-36691, 2007.

[98] G. R. Chichili and W. Rodgers, "Cytoskeleton-membrane interactions in membrane raft structure," Cellular and Molecular Life Sciences, vol. 66, no. 14, pp. 2319-2328, 2009.

[99] H. L. Yin and P. A. Janmey, "Phosphoinositide regulation of the actin cytoskeleton," Annual Review of Physiology, vol. 65, pp. 761-789, 2003.

[100] M. P. Czech, "Signal transduction: lipid rafts and insulin action," Nature, vol. 407, no. 6801, pp. 147-148, 2000.

[101] J. E. Harlan, P. J. Hajduk, H. S. Yoon, and S. W. Fesik, "Pleckstrin homology domains bind to phosphatidylinositol4,5-bisphosphate," Nature, vol. 371, no. 6493, pp. 168-170, 1994.

[102] P. Várnai and T. Balla, "Visualization of phosphoinositides that bind pleckstrin homology domains: calcium- and agonist-induced dynamic changes and relationship to myo$[\mathrm{H}]$ inositol-labeled phosphoinositide pools," Journal of Cell Biology, vol. 143, no. 2, pp. 501-510, 1998.

[103] G. Lemon, W. G. Gibson, and M. R. Bennett, "Metabotropic receptor activation, desensitization and sequestration - I: modelling calcium and inositol 1,4,5-trisphosphate dynamics following receptor activation," Journal of Theoretical Biology, vol. 223, no. 1, pp. 93-111, 2003.

[104] N. Funatsu, H. Kumanogoh, Y. Sokawa, and S. Maekawa, "Identification of gelsolin as an actin regulatory component in a Triton insoluble low density fraction (raft) of newborn bovine brain," Neuroscience Research, vol. 36, no. 4, pp. 311$317,2000$.

[105] S. Ilschner and R. Brandt, "The transition of microglia to a ramified phenotype is associated with the formation of stable acetylated and detyrosinated microtubules," Glia, vol. 18, no. 2, pp. 129-140, 1996.
[106] C. Conde and A. Cáceres, "Microtubule assembly, organization and dynamics in axons and dendrites," Nature Reviews Neuroscience, vol. 10, no. 5, pp. 319-332, 2009.

[107] M. F. Tsan and R. D. Berlin, "Effect of phagocytosis on membrane transport of nonelectrolytes," Journal of Experimental Medicine, vol. 134, no. 4, pp. 1016-1035, 1971.

[108] G. M. Edelman, I. Yahara, and J. L. Wang, "Receptor mobility and receptor-cytoplasmic interactions in lymphocytes," Proceedings of the National Academy of Sciences of the United States of America, vol. 70, no. 5, pp. 1442-1446, 1973.

[109] J. M. Oliver, T. E. Ukena, and R. D. Berlin, "Effects of phagocytosis and colchicine on the distribution of lectin binding sites on cell surfaces," Proceedings of the National Academy of Sciences of the United States of America, vol. 71, no. 2, pp. 394-398, 1974.

[110] B. P. Ceresa and S. L. Schmid, "Regulation of signal transduction by endocytosis," Current Opinion in Cell Biology, vol. 12, no. 2, pp. 204-210, 2000.

[111] R. F. Stump, J. R. Pfeiffer, J. Seagrave, and J. M. Oliver, "Mapping gold-labeled IgE receptors on mast cells by scanning electron microscopy: receptor distributions revealed by silver enhancement, backscattered electron imaging, and digital image analysis," Journal of Histochemistry and Cytochemistry, vol. 36, no. 5, pp. 493-502, 1988.

[112] S. Y. Mao, J. R. Pfeiffer, J. M. Oliver, and H. Metzger, "Effects of subunit mutation on the localization to coated pits and internalization of cross-linked IgE-receptor complexes," Journal of Immunology, vol. 151, no. 5, pp. 2760-2774, 1993.

[113] J. S. Bonifacino and L. M. Traub, "Signals for sorting of transmembrane proteins to endosomes and lysosomes," Annual Review of Biochemistry, vol. 72, pp. 395-447, 2003.

[114] B. S. Wilson, S. L. Steinberg, K. Liederman et al., "Markers for detergent-resistant lipid rafts occupy distinct and dynamic domains in native membranes," Molecular Biology of the Cell, vol. 15, no. 6, pp. 2580-2592, 2004.

[115] B. S. Wilson, J. R. Pfeiffer, Z. Surviladze, E. A. Gaudet, and J. M. Oliver, "High resolution mapping of mast cell membranes reveals primary and secondary domains of FceRI and LAT," Journal of Cell Biology, vol. 154, no. 3, pp. 645-658, 2001.

[116] V. M. Mazucato, A. M. Silveira e Souza, L. M. Nicoletti, M. C. Jamur, and C. Oliver, "GD1b-derived gangliosides modulate FceRI endocytosis," Journal of Histochemistry and Cytochemistry. In press.

[117] P. S. McPherson, B. K. Kay, and N. K. Hussain, "Signaling on the endocytic pathway," Traffic, vol. 2, no. 6, pp. 375-384, 2001.

[118] R. Molfetta, F. Gasparrini, A. Santoni, and R. Paolini, "Ubiquitination and endocytosis of the high affinity receptor for IgE," Molecular Immunology, vol. 47, no. 15, pp. 24272434, 2010.

[119] F. Lafont and K. Simons, "Raft-partitioning of the ubiquitin ligases $\mathrm{Cbl}$ and Nedd4 upon IgE-triggered cell signaling," Proceedings of the National Academy of Sciences of the United States of America, vol. 98, no. 6, pp. 3180-3184, 2001.

[120] K. F. Harvey and S. Kumar, "Nedd4-like proteins: an emerging family of ubiquitin-protein ligases implicated in diverse cellular functions," Trends in Cell Biology, vol. 9, no. 5, pp. 166-169, 1999.

[121] P. S. Freemont, "Ubiquitination: RING for destruction?" Current Biology, vol. 10, no. 2, pp. R84-R87, 2000.

[122] Y. Ota, L. O. Beitz, A. M. Scharenberg, J. A. Donovan, J. P. Kinet, and L. E. Samelson, "Characterization of Cbl tyrosine phosphorylation and a Cbl-Syk complex in RBL-2H3 cells," 
Journal of Experimental Medicine, vol. 184, no. 5, pp. 1713$1723,1996$.

[123] Y. Ota and L. E. Samelson, "The product of the protooncogene c-cbl: a negative regulator of the Syk tyrosine kinase," Science, vol. 276, no. 5311, pp. 418-420, 1997.

[124] R. Molfetta, F. Gasparrini, G. Peruzzi et al., "Lipid raftdependent FceRI ubiquitination regulates receptor endocytosis through the action of ubiquitin binding adaptors," PLoS One, vol. 4, no. 5, article e5604, 2009.

[125] R. Molfetta, F. Gasparrini, A. Santoni, and R. Paolini, "Ubiquitination and endocytosis of the high affinity receptor for IgE," Molecular Immunology, vol. 47, no. 15, pp. 24272434, 2010.

[126] K. A. Field, J. R. Apgar, E. Hong-Geller, R. P. Siraganian, B. Baird, and D. Holowka, "Mutant RBL mast cells defective in FceRI signaling and lipid raft biosynthesis are reconstituted by activated Rho-family GTPases," Molecular Biology of the Cell, vol. 11, no. 10, pp. 3661-3673, 2000.

[127] H. Metzger, "It's spring, and thoughts turn to ... allergies," Cell, vol. 97, no. 3, pp. 287-290, 1999.

[128] N. Hanai, G. A. Nores, C. MacLeod, C. R. Torres-Mendez, and S. Hakomori, "Ganglioside-mediated modulation of cell growth. Specific effects of GM and lyso-GM in tyrosine phosphorylation of the epidermal growth factor receptor," Journal of Biological Chemistry, vol. 263, no. 22, pp. 1091510921, 1988.

[129] F. M. B. Weis and R. J. Davis, "Regulation of epidermal growth factor receptor signal transduction. Role of gangliosides," Journal of Biological Chemistry, vol. 265, no. 20, pp. 12059-12066, 1990.

[130] B. Baird, E. D. Sheets, and D. Holowka, "How does the plasma membrane participate in cellular signaling by receptors for immunoglobulin E?" Biophysical Chemistry, vol. 82, no. 2-3, pp. 109-119, 1999.

[131] X. Q. Wang, P. Sun, and A. S. Paller, "Ganglioside modulation regulates epithelial cell adhesion and spreading via ganglioside-specific effects on signaling," Journal of Biological Chemistry, vol. 277, no. 43, pp. 40410-40419, 2002.

[132] R. F. Stump, J. R. Pfeiffer, M. C. Schneebeck, J. C. Seagrave, and J. M. Oliver, "Mapping gold-labeled receptors on cell surfaces by backscattered electron imaging and digital image analysis: studies of the IgE receptor on mast cells," American Journal of Anatomy, vol. 185, no. 2-3, pp. 128-141, 1989.

[133] D. A. Brown and E. London, "Structure and function of sphingolipid- and cholesterol-rich membrane rafts," Journal of Biological Chemistry, vol. 275, no. 23, pp. 17221-17224, 2000.

[134] T. P. Stauffer and T. Meyer, "Compartmentalized IgE receptor-mediated signal transduction in living cells," Journal of Cell Biology, vol. 139, no. 6, pp. 1447-1454, 1997.

[135] P. S. Pyenta, D. Holowka, and B. Baird, "Cross-correlation analysis of inner-leaflet-anchored green fluorescent protein co-redistributed with IgE receptors and outer leaflet lipid raft components," Biophysical Journal, vol. 80, no. 5, pp. 2120 2132, 2001.

[136] N. Kato, M. Nakanishi, and N. Hirashima, "Flotillin-1 regulates IgE receptor-mediated signaling in rat basophilic leukemia (RBL-2H3) cells," Journal of Immunology, vol. 177, no. 1, pp. 147-154, 2006.

[137] T. Yamashita, T. Yamaguchi, K. Murakami, and S. Nagasawa, "Detergent-resistant membrane domains are required for mast cell activation but dispensable for tyrosine phosphorylation upon aggregation of the high affinity receptor for IgE," Journal of Biochemistry, vol. 129, no. 6, pp. 861-868, 2001.
[138] N. H. Fifadara, C. C. Aye, S. K. Raghuwanshi, R. M. Richardson, and S. J. Ono, "CCR1 expression and signal transduction by murine BMMC results in secretion of TNF$\alpha$, TGF $\beta-1$ and IL-6," International Immunology, vol. 21, no. 8, pp. 991-1001, 2009.

[139] D. Volonté, F. Galbiati, S. Li, K. Nishiyama, T. Okamoto, and M. P. Lisanti, "Flotillins/cavatellins are differentially expressed in cells and tissues and form a hetero-oligomeric complex with caveolins in vivo: characterization and epitopemapping of a novel flotillin-1 monoclonal antibody probe," Journal of Biological Chemistry, vol. 274, no. 18, pp. 1270212709, 1999.

[140] P. E. Bickel, P. E. Scherer, J. E. Schnitzer, P. Oh, M. P. Lisanti, and H. F. Lodish, "Flotillin and epidermal surface antigen define a new family of caveolae-associated integral membrane proteins," Journal of Biological Chemistry, vol. 272, no. 21, pp. 13793-13802, 1997.

[141] M. L. Stracke, L. K. Basciano, and R. P. Siraganian, "Binding properties and histamine release in variants of rat basophilic leukemia cells with changes in the IgE receptor," Immunology Letters, vol. 14, no. 4, pp. 287-292, 1987.

[142] V. Stephan, N. Guo, V. Ginsburg, and R. P. Siraganian, "Immunoprecipitation of membrane proteins from rat basophilic leukemia cells by the antiganglioside monoclonal antibody AA4," Journal of Immunology, vol. 146, no. 12, pp. 4271-4277, 1991.

[143] K. Minoguchi, W. D. Swaim, E. H. Berenstein, and R. P. Siraganian, "Src family tyrosine kinase p53/56 lyn, a serine kinase and FceRI associate with $\alpha$-galactosyl derivatives of ganglioside $\mathrm{GD}_{\mathrm{lb}}$ in rat basophilic leukemia RBL-2H3 cells," Journal of Biological Chemistry, vol. 269, no. 7, pp. 52495254, 1994.

[144] W. D. Swaim, K. Minoguchi, C. Oliver et al., "The antiganglioside monoclonal antibody AA4 induces protein tyrosine phosphorylations, but not degranulation, in rat basophilic leukemia cells," Journal of Biological Chemistry, vol. 269, no. 30, pp. 19466-19473, 1994.

[145] M. C. Jamur, A. C. G. Grodzki, A. N. Moreno, W. D. Swaim, R. P. Siraganian, and C. Oliver, "Immunomagnetic isolation of rat bone marrow-derived and peritoneal mast cells," Journal of Histochemistry and Cytochemistry, vol. 45, no. 12, pp. 1715-1722, 1997.

[146] M. C. Jamur, A. C. G. Grodzki, A. N. Moreno et al., "Identification and isolation of rat bone marrow-derived mast cells using the mast cell-specific monoclonal antibody AA4," Journal of Histochemistry and Cytochemistry, vol. 49, no. 2, pp. 219-228, 2001.

[147] C. D. Faraco, I. Vugman, R. P. Siraganian, M. C. Jamur, and C. Oliver, "Immunocytochemical identification of immature rat peritoneal mast cells using a monoclonal antibody specific for rat mast cells," Acta Histochemica, vol. 99, no. 1, pp. 2327, 1997.

[148] P. Valent, C. Sillaber, and P. Bettelheim, "The growth and differentiation of mast cells," Progress in Growth Factor Research, vol. 3, no. 1, pp. 27-41, 1991.

[149] M. C. Jamur, A. C. G. Grodzki, E. H. Berenstein, M. M. Hamawy, R. P. Siraganian, and C. Oliver, "Identification and characterization of undifferentiated mast cells in mouse bone marrow," Blood, vol. 105, no. 11, pp. 4282-4289, 2005. 

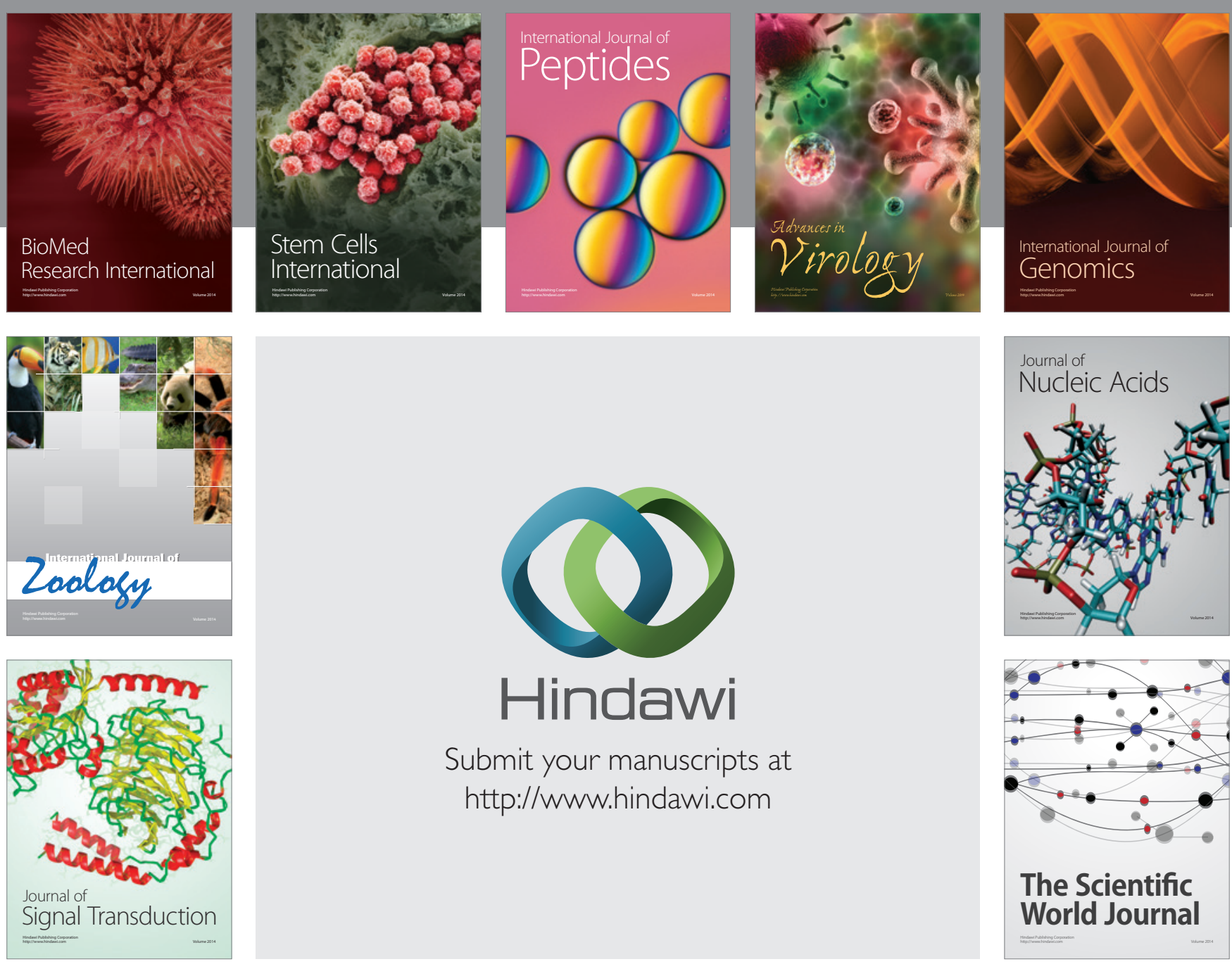

Submit your manuscripts at

http://www.hindawi.com
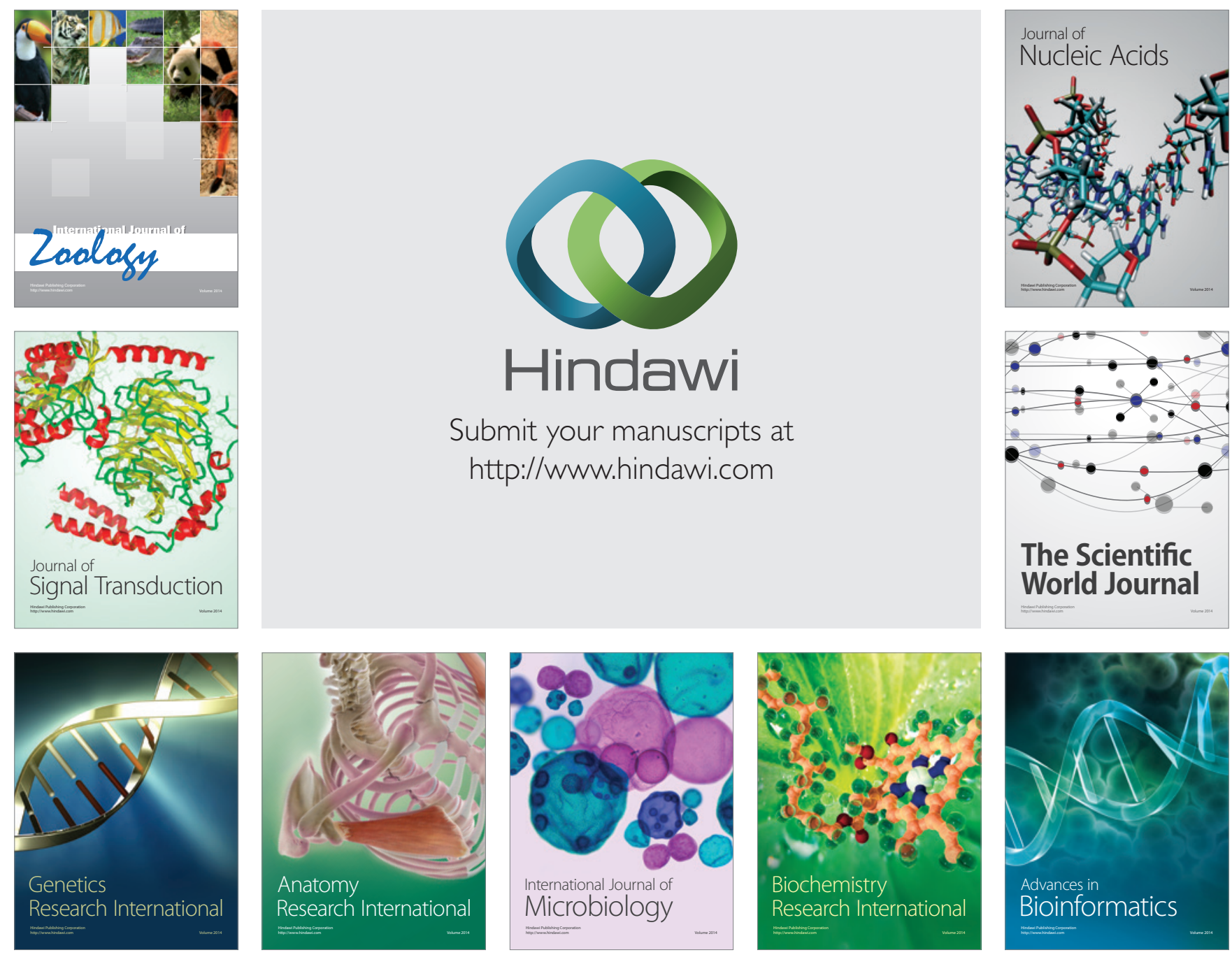

The Scientific World Journal
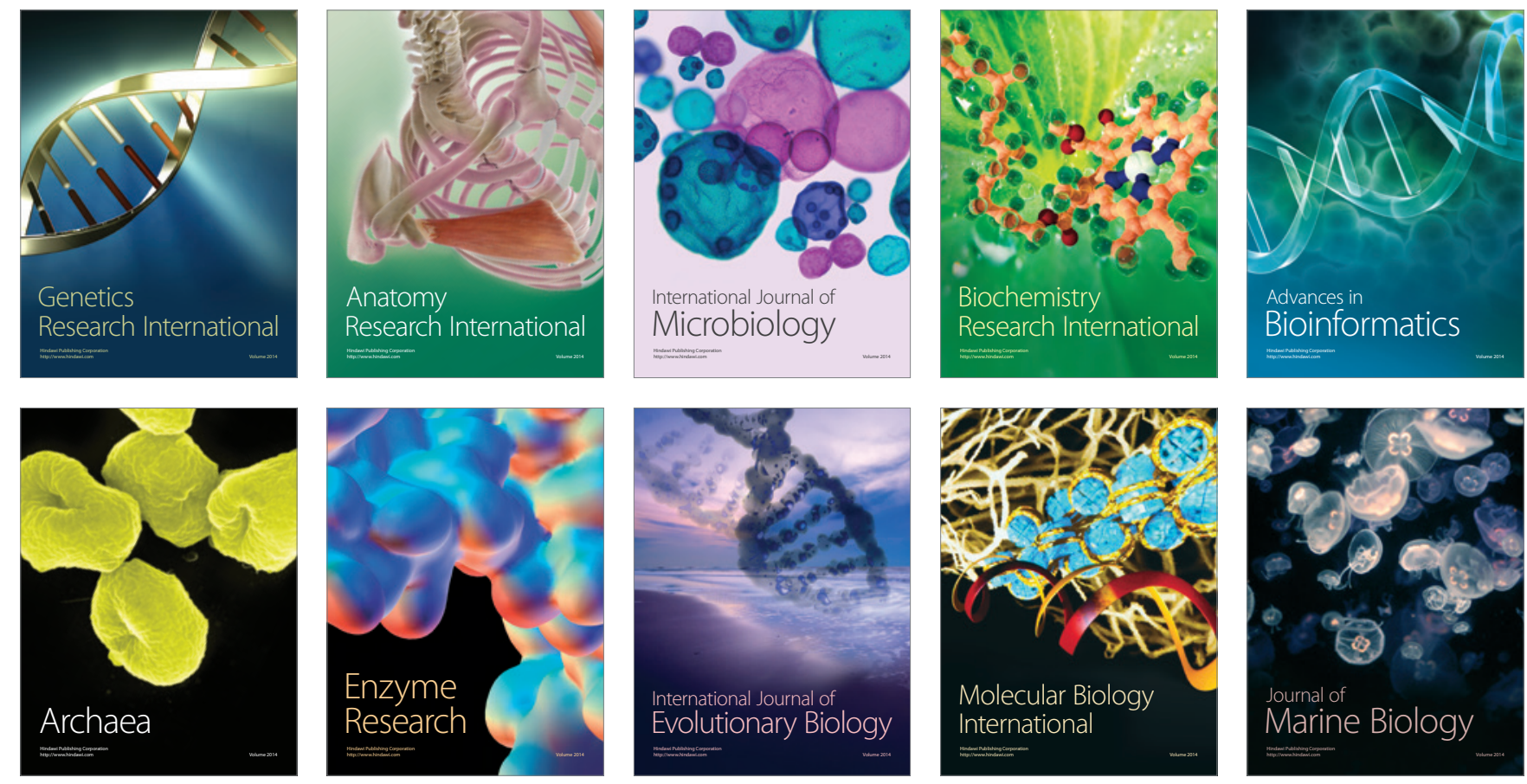